\title{
The European Union as a Pan-European Project
}

\author{
Wilfried LOTH
}

\begin{abstract}
In the first plans for European integration presented in the years after World War I a borderline between Eastern Europe and Western Europe was never envisaged. People from Middle and Eastern Europe articulated them in the same perspective as people from Western Europe, and this perspective was a pan-European one. As a consequence, overcoming the communist rule in the countries of the Soviet bloc in Europe remained one of the reasons of the process of European integration; and the inclusion of the countries of the former communist bloc in this process became inevitable as soon as the communist rule collapsed.

Keywords: European Movement, Governments in Exile, Marshall Plan, Plans for European Integration, Resistance
\end{abstract}

Contemporaries of the Cold War saw the European Union mostly as an element of Western integration and Western block building. As a consequence, the hostile attitude of the Soviet Union towards the efforts to integrate Western Europe seemed quite natural, and even if Soviet officials had great difficulties to explain the success of these efforts in terms of Marxist-Leninist theory, ${ }_{1}$ the enduring tensions between the European Communities and the Soviet Union could be easily understood. When after the collapse of the Soviet bloc former member countries aimed at becoming members of the EU this was usually interpreted as an expansion of the integrated West.

However, if we look more closely on the beginnings of European integration we can discover that the integrated Europe was much more than a consequence of the Cold War and that, as a consequence, the hostility of the Soviet Union towards the EU was not as inevitable as it seems to have been. Broadly speaking, four different driving forces can be recognized behind the process of European integration: the maintenance of peace among sovereign states in Europe; the resolving of the German question - that is the problem of a potentially dominant state in the middle of the European continent; the preservation of economic productivity in a time of national markets in Europe becoming too small for rational production methods; finally the self-assertion in the face of the new world powers, the US as well as the Soviet Union. ${ }^{2}$ It should be no surprise that such motives emerged not only in the Westerns parts of the European continent but in its Eastern parts as well.

1 See Wolfgang Müller, "The Soviet Union and Early West European Integration”, in: Journal of European Integration History 15 (2009/2), pp. 67-85.

2 For a general view, see Wilfried Loth, "Explaining European Integration: The Contribution from Historians”, in: Journal of European Integration History 14 (2008/1), pp. 9-26. 
In the first plans for European integration presented in the years after World War I a borderline between Eastern Europe and Western Europe was never envisaged. People from Middle and Eastern Europe articulated them in the same perspective as people from Western Europe, and this perspective was a pan-European one. The only dispute splitting the adherents of the European idea was if Great Britain should become a member of a united Europe or not. Richard Coudenhove-Kalergi in his book on "Paneuropa" did not envisage a British participation whereas the adherents of the "Union for a European Understanding" aimed at a strong connection with the Brits. The representatives of middle and east European countries had a considerable part in the activities and congresses of the European movement; their unions had their offices in Budapest and Prague as well as in Brussels, Paris and Vienna. The strongest groups of Coudenhove's "Pan-European Union" and the "European Customs Union" directed by the Hungarian economist Elmer Hantos were established in the capitals of Middle and Eastern Europe. The cartel of Western European steel producers established in 1926 due to the efforts of Emile Mayrisch was joined one year later by the steel producers of Austria, Hungary and Czechoslovakia. ${ }^{3}$ In the planning of European integration during the years of World War $\mathrm{II}^{4}$ the Eastern Europeans were also participating at the same degree as the Western Europeans. Even more: This time, the most specific and detailed planning was developed by the representatives of the exiles and resistance of Eastern Europe. As early as 11 November 1940, the Polish government in exile under General Wladysław Sikorski and the provisional Czech government under President Eduard Beneš had issued a joint declaration of their intention "to enter, as independent and sovereign states, into a closer political and economic association" which was to be joined by "other countries in that part of the European

3 Walter Lipgens, A History of European Integration 1945-1947. The Formation of the European Unity Movement, Oxford: Clarendon Press 1982, pp. 35-44; Anita Ziegerhofer-Prettenthaler, Botschafter Europas. Richard Nikolaus Coudenhove-Kalergi und die Paneuropa-Bewegung in den zwanziger und dreißiger Jahren, Vienna: Böhlau 2004; Oliver Burgard, Das gemeinsame Europa - von der politischen Utopie zum außenpolitischen Programm. Meinungsaustausch und Zusammenarbeit proeuropäischer Verbände in Deutschland und Frankreich 1924-1933, Frankfurt/Main, 2000; Włodzimierz Borodziej / Heinz Duchhardt / Małgorzata Morawiec / Ignác Romsics (eds.), Option Europa. Deutsche, polnische und ungarische Europapläne des 19.und 20. Jahrhunderts, 3 vols., Göttingen: Vandenhoeck \& Ruprecht, 2005; Vladimír Goněc, ,Milan Hodža before Milan Hodža. His early schemes and concepts of Europe”, in: Vladimír Goněc (ed.), In Between Enthusiasm and Pragmatism: How to Construct Europe? Six Studies, Brno: Masaryk University, 2008, pp. 66-112.

4 See Wilfried Loth, "Sources of European Integration: The Meaning of Failed Interwar Politics and the Role of World War II", in: Ludger Kühnhardt (ed.), Crises in European Integration. Challenges and Responses, 1945 - 2005, New York / Oxford: Berghahn, 2009, pp. 19-32; Walter Lipgens (ed.), Documents on the History of European Integration. Vol. 1: Continental Plans for European Union, 1939-1945; Vol. 2: Plans for European Union in Great Britain and in Exile, 1939-1945, Berlin / New York: de Gruyter, 1985/1986. 
continent". ${ }^{5}$ On 23 January 1942, the two governments concluded a formal agreement in which they undertook to form a Polish-Czechoslovakian "confederation" after the war. They agreed that periodical meetings of the deputies and governments of both countries should provide a close coordination and the development of common policies of both countries.

Sikorski and the Polish government in exile wanted to go even further. Their plan for a union with Czechoslovakia envisaged the establishment of common ministries of Foreign affairs, Defense and Common Economic affairs as well as the organization of a common General Staff in times of war. The "Federal government" constituted in this way should be controlled by a Parliamentary Assembly and a "Highest Council". However, Beneš who was very skeptical on the federal idea and more interested in economic integration rather than in political-military unification could not be convinced to agree on more than on the confederative form of association. So, in the construction agreed in January 1942 the national governments preserved the last word in any case of conflict.

During the same time as the Polish and the Czechoslovakian governments in exile the governments of Yugoslavia and Greece negotiated a bilateral association, too; and the conflict lines between them were similar. In this case, it was the government in exile of Yugoslavia and especially the Foreign minister Ničič who aimed at a federative form of the planned Union of the Balkans - including a common chancellor and common authorities on political, military and economic questions based on the respective national ministries. The member countries of the Union should strive for an economic and monetary union and a common army; furthermore, they should coordinate their foreign policy. In contrast to this, the Greeks wanted to minimize the degree of integration. However, differently from the case of the Polish-Czechoslovakian Union it were the federalists who succeeded in these negotiations, due to an intervention by British Foreign minister Anthony Eden: The confederation agreement signed by both governments on 15 January 1942 included the organization of a "common office" charged to execute the decisions of the common authorities. Among the purposes of the Union both the creation of an economic and monetary union and the organization of a common General Staff were agreed. ${ }^{6}$

5 Text in The Times, 12 Nov. 1942. Cf. Walter Lipgens, "East European Plans for the Future of Europe: The Example of Poland", in: Documents, vol. 1, pp. 609-658; Feliks M. Goss and M. Kamil Dziewanowski, "Plans by Exiles from East European Countries", in: Documents, vol. 2, pp. 353-413; Feliks Gross, "Views of East European Transnational Groups on the Postwar Order in Europe", ibid., pp. 754-785; Jósef Łaptos and Marius Misztal, American Debates on Central European Union 1942-1944. Documents of the American State Department, Brussels: P.I.E. Peter Lang, 2002; Vladimír Goněc, Hubert Ripka: un Européen, Brno: Masaryk University, 2006, pp. 46-78.

6 Detlef Brandes, "Confederation plans in Eastern Europe during World War II", in: Michel Dumoulin (ed.), Wartime Plans for Postwar Europe 1940-1947, Brussels: Bruylant, 1995, pp. 83-94. 
The great majority of those belonging to the Eastern European resistance, drawn mostly from the ranks of the political center and the socialist left, saw in these agreements the prelude to a federalization of the Eastern European region within an overall European context. A number of figures turned their attention to a combination of Eastern-Central European federation, Danube federation, and Balkan federation; others, including Sikorski, wanted to gather the whole of Eastern-Central and South-Eastern Europe into one federation. At a meeting with King Peter II of Yugoslavia, immediately after the signature of the agreement between Yugoslavia and Greece, Beneš called the two confederations "the base for a more comprehensive treaty and a general peace settlement in Middle and Southeastern Europe". The King declared himself in favor of cooperation between his country and Czechoslovakia in the framework of an "international community of Europe". ${ }^{7}$ However, for the Greek government this connection between the Middle-European and the Southeastern European Confederation went too far, at least for the time being: The Greeks didn't want to be involved in the disputes of Poland with the Soviet Union. Within the Yugoslavian government even a possible extension of the Balkan confederation on Bulgaria met on opposition. As a consequence, the governments of Yugoslavia and Greece agreed in November 1942 to postpone negotiations on the possible inclusion of neighbor countries of the Soviet Union in the confederation after a settlement of territorial and political disputes of these countries with the Soviet Union.

The integration of the regional federations into a greater Europe was discussed for the first time at a round of meetings organized by Sikorski at the headquarters of most of the governments in exile in London. At his invitation, representatives of Poland, Czechoslovakia, Norway, Belgium, the Netherlands, Luxemburg, Greece, and Yugoslavia as well as the "Free France" Committee met to air their views on the organization of a "European community". The negotiations lasted for the whole of 1942, and in the process, it became apparent that there was considerable agreement on the need to surrender sovereignty to the community and for the participant states to be organized democratically. It was also clear, however, that it was no longer feasible to decide on the overall structure of Europe without the involvement of the new world powers and that the problem of securing peace could in any event no longer be solved predominantly on the European level. ${ }^{8}$

It is common wisdom in most of the literature that these federation or confederation plans for the Eastern region of Europe failed due to the veto of the Soviet Union. ${ }^{9}$ This is not entirely correct. When in December 1941 British foreign minister Eden negotiated with Joseph Stalin about the postwar settlement for

$7 \quad$ Ibid. p. 86.

8 See the report by Paul Henri Spaak, Memoiren eines Europäers, Hamburg: Hoffman und Campe, 1969, p. 117. A detailed reconstruction of these talks is still lacking.

9 See Lipgens, A History, pp. 68-72. 
Europe the Soviet leader declared to have "no objections against the founding of state federations in Europe". ${ }^{10}$ He did not fundamentally reject Churchill's concept of a "European Council" in the framework of the United Nations. At the Tehran Conference in November of 1943 he only insisted that the United States as well as the Soviet Union should be members of the European Council, as well as of the Asiatic one. A European Council without Soviet participation seemed to him too insecure vis-à-vis the risk posed by Germany as well as the antiSoviet tendencies in Eastern Europe, and might even emerge as an instrument for the formation of an imperialist power block under British leadership. ${ }^{11}$ The first and most comprehensive war objectives programme of the Moscow leadership, edited by the chairman of the Commission for the Planning for Reparations to be Extracted from the Defeated Enemy States, Ivan Maiskii, and handed to Foreign Minister Vyacheslav Molotov on 11 January 1944, simply stated that it would not be "in the interest of the Soviet Union to promote the creation of federations of different kinds" in Europe, "at least during the first period after the war". ${ }^{12}$

At close look, the federation plans for Eastern Europe failed due to the PolishSoviet quarrel about the Eastern borderline of Poland. In order to avoid an involvement in this dispute Beneš declared in November of 1942 that he considered the time "not yet ripe" for the realization of the federation project with Poland. When Stalin broke off diplomatic relations with the Polish government in exile in May of 1943, Beneš likewise ended the negotiations with the Poles. ${ }^{13}$ After this break in the other circles of Eastern European exiles support for federation plans rapidly dwindled too; to pursue them in light of the Soviet-Polish dispute seemed neither sensible nor realistic. Following Sikorski's death in an air crash in July of 1943, discussions among the governments in exile in London were not pursued any further. ${ }^{14}$

10 Conversation Stalin - Eden 16 December 1941, Soviet minutes in: Georgij P. Kynin / Jochen Laufer (eds.), SSSR I germanskij vopros 1941-1949. Vol. 1: 22 ijunja 1941 g. - 8 maja 1945 g, Moskva: Meshdunarodnye Otnoscheija, 1996, pp. 124-135.

11 See Keith Sainsbury, The Turning Point. Roosevelt, Stalin, Churchill and Chiang-Kai-Shek, 1943. The Moscow, Cairo and Teheran Conferences, Oxford/New York: Oxford University Press, 1985.

12 Published in: Istocnik, 4/1995, pp. 124-144; reprinted in SSSR I germanskij vopros, Vol. 1, pp. 333-360. On the context see Geoffrey Roberts, Stalin's War. From World War to Cold War, 1939-1953, New Haven / London: Yale University Press, 2006; Wilfried Loth, Die Sowjetunion und die deutsche Frage. Studien zur sowjetischen Deutschlandpolitik von Stalin bis Chruschtschow, Göttingen: Vandenhoeck \& Ruprecht, 2007, pp. 27-47; Jochen Laufer, Pax Sovietica. Stalin, die Westmächte und die deutsche Frage 1941-1945, Köln: Böhlau, 2009.

13 Piotr S. Wandycz, Czechoslovak-Polish Confederation and the Great Powers 1940-1943, Bloomington: Indiana University Publications, 1956, pp. 75-88.

14 Gross, Views of East European Transnational Groups, p. 759. 
This end of official negotiations notwithstanding representatives of the democratic forces in the countries of Middle and Eastern Europe continued to look after possibilities to realize the federation plans and to engage themselves for these plans in public, as long as the completion of Communist power control did not yet prevent them to do so. For instance, in 1945-46 the Chairman of the Committee of Foreign Affairs in the Hungarian Parliament, Paul von Auer continuously propagated the creation of Danubian federation in the framework of "United States of Europe". The governments of Hungary and Romania worked for a comprehensive bilateral settlement and the preparation of a customs union. In April 1947 the Chairman of the European Union of Federalists, Henri Brugmans was invited to Prague to prepare the foundation of a Czechoslovakian section of this federalist movement. If in Poland the liberty of action for federalists was already much more restricted after the establishment of the Lublin committee, Polish politicians who had remained in exile or were forced to leave the country once again in 1947 were strongly in favor of the federalist idea. In a poll organized by Coudenhove-Kalergi 89 percent of them declared their support for the integration plans. ${ }^{15}$

Given these circumstances it was no surprise that the overwhelming majority of the organized European movement in the Western parts of the European continent didn't see their project in the first stance not as a Western project to contain the danger of Soviet expansionism but on the contrary as a means to avoid the division of Europe into East and West. As Brugmans said at his visit in Prague: "What European federalism can offer Czechoslovakia is the following: there will be no attempt to detach the country from the USSR or Slav solidarity", but "the object is to keep the Slavic world in Europe open in both directions and not confront these nations with a choice between Russia and the West. A United Europe will make it possible to work with both" ${ }^{16}$ A basic resolution issued by the enlarged Central Committee of the Union of Federalists stated in April 1947: "that a European Federation is essential to overcome bloc politics and thus to avoid a new conflict which would be the inevitable result of the division of the world into spheres of influence". ${ }^{17}$

During the years 1945 to 1947, only a few Europeans welcomed the concept of integrating Western Europe within a Western bloc. When Winston Churchill, in his Zurich speech of September 19, 1946 called for the creation of "a kind of United States of Europe" which was to defend against the "approach of some new peril, tyranny, or terror", - that is: a Western Europe which was to defend against Soviet expansionism - he reaped much more opposition than consent. ${ }^{18}$ This was

15 Lipgens, A History, pp. 444-457; Goněc, Ripka, pp. 79-90.

16 Lipgens, A History, pp. 448f.

17 Ibid. p. 381.

18 Text in: Walter Lipgens / Wilfried Loth (eds.), Documents on the History of European Integration, Vol. 3: The Struggle for European Union by Political Parties and Pressure 
the major reason why the Truman administration offered its Marshall Aid program not only to the countries of Western Europe but also to those of Eastern Europe and to the Soviet Union. The US didn't want to take over the burden of responsibility for the division of the European continent. ${ }^{19}$

By rejecting the Marshall offer Stalin who believed himself much cleverer than the degenerated imperialists, stepped into this trap. ${ }^{20}$ The numerous advocates of a Europe of the "Third force" between East and West could only react by opting for a "Begin in the West". However, it should be noted that they argued just in favor of a "begin". They took this decision hesitantly and with the conviction that even a union of the Western European countries only could and would work in favor of an overcoming of the blocs. As the Italian federalist Altiero Spinelli put it on the congress of the European Union of Federalists in August 1947 in Montreux: "A European federation, even a partial one, will possess that independence vis-à-vis America that the Western states can no longer achieve individually. Such a federation can further restrain and finally do away with the pernicious policy of spheres of influence $[\ldots]$ it can gradually bring back the values and institutions of democratic civilization to those countries which have departed from them". ${ }^{21}$

I must admit that not all supporters of real existing process of European integration since 1950 did share these long-term aims. Also, during the long experience of a bi-polar world the Pan-European perspective was simply forgotten by many of them. Nevertheless, overcoming the communist rule in the countries of the Soviet bloc in Europe remained one of the reasons of the process of European integration; and the inclusion of the countries of the former communist bloc in this process became inevitable as soon as the communist rule collapsed. Politicians and citizens of the EU had to admit that, as the Federalists in Montreux had stated in August 1947, "it is impossible in the final event to achieve a closely knit Europe for which life is possible unless all its constituent countries, north, south, east and west, pool their complementary qualities and economies", and that "the traditions and culture of each of these peoples are part and parcel of the common European heritage". ${ }^{22}$

Groups in Western European Countries 1945-1950, Berlin / New York: de Gruyter, 1988, pp. 662-666. On the reaction, see pp. Lipgens, A History, pp. 341-347.

19 See Wilfried Loth, "The Marshall Plan and European unification: Impulses and Restraints", in: John Agnew / J. Nicholas Entrikin (eds.), The Marshall Plan Today: Model and Metaphor, London / New York: Routledge, 2004, pp. 217-233.

20 See Scott D. Parish, "The Marshall Plan, Soviet-American-Relations, and the Division of Europe", in: Norman Naimark / Leonid Gibianski (eds.), The Establishment of Communist Regimes in Eastern Europe, 1944-1949, Boulder, Co., 1997, pp. 267-290; Mikhail M. Narinsky, "Sovětský svaz a Marshallûv plán. Ještě k otázce sovětského veta", in: Soudobé dějiny 4 (1997/3-4), pp. 479-491.

21 Lipgens, A History, p. 582.

22 Ibid. p. 583. 
Given this historical background, the Eastern enlargement of the EU in 2004 and the following years was in the first place not an expansion of the West but a long awaited completion of the beginnings in the late 1940's and early 1950's. When on the $1^{\text {st }}$ of May 2004 the heads of 25 states and governments and their Foreign Ministers met in Phoenix Castle near Dublin to celebrate the accession of 10 new member states, it was Lithuana's Foreign Minister Sandra Kalniete who coined the sentence of the day: "This is Europe's triumph over the $20^{\text {th }}$ century" ${ }^{23}$ It is important to see that she was right.

\section{Bibliography}

Borodziej, Włodzimierz/Heinz Duchhardt / Małgorzata Morawiec / Ignác Romsics (eds.). Option Europa. Deutsche, polnische und ungarische Europapläne des 19. und 20. Jahrhunderts, 3 vols., Göttingen: Vandenhoeck \& Ruprecht, 2005.

Brandes, Detlef: "Confederation plans in Eastern Europe during World War II", in: Michel Dumoulin (ed.), Wartime Plans for Postwar Europe 1940-1947, Brussels: Bruylant 1995, 83-94.

Burgard, Oliver: Das gemeinsame Europa - von der politischen Utopie zum außenpolitischen Programm. Meinungsaustausch und Zusammenarbeit proeuropäischer Verbände in Deutschland und Frankreich 1924-1933, Frankfurt/Main, 2000.

Goněc, Vladimír: Hubert Ripka: un Européen, Brno: Masaryk University, 2006.

Goněc, Vladimír: „Milan Hodža before Milan Hodža. His early schemes and concepts of Europe", in: Vladimír Goněc (ed.), In Between Enthusiasm and Pragmatism: How to Construct Europe? Six Studies, Brno: Masaryk University, 2008, 66-112.

Kynin, Georgij P. / Jochen Laufer (eds.): SSSR I germanskij vopros 1941-1949. Vol. 1: 22 ijunja 1941 g. - 8 maja 1945 g, Moskva: Meshdunarodnye Otnoscheija 1996.

Łaptos, Jósef / Marius Misztal: American Debates on Central European Union 1942-1944. Documents of the American State Department, Brussels: P.I.E. Peter Lang, 2002.

Laufer, Jochen: Pax Sovietica. Stalin, die Westmächte und die deutsche Frage 1941-1945, Köln: Böhlau, 2009.

Lipgens, Walter: A History of European Integration 1945-1947. The Formation of the European Unity Movement, Oxford: Clarendon Press, 1982.

Lipgens, Walter (ed.): Documents on the History of European Integration. Vol. 1: Continental Plans for European Union, 1939-1945; Vol. 2: Plans for European Union in Great Britain and in Exile, 1939-1945, Berlin / New York: de Gruyter, 1985/1986.

Lipgens, Walter / Wilfried Loth (eds.): Documents on the History of European Integration, Vol. 3: The Struggle for European Union by Political Parties and Pressure Groups in Western European Countries 1945-1950, Berlin / New York: de Gruyter, 1988.

Loth, Wilfried: "The Marshall Plan and European unification: Impulses and Restraints", in: John Agnew / J. Nicholas Entrikin (eds.), The Marshall Plan Today: Model and Metaphor, London / New York: Routledge 2004, 217-233.

23 Günter Verheugen, Europa in der Krise. Für eine Neubegründung der europäischen Idee, Köln: Kiepenheuer \& Witsch, 2005, p. 63. - For an assessment of the enlargement of 2004/2007 see Antoine Marès, "Central Europe in the 'Fifth' Enlargement of the European Union", in: Wilfried Loth (ed.), Experiencing Europe.50 Years of European Construction 1957-2007, Baden-Baden: Nomos, 2009, pp. 326-345. 
Loth, Wilfried: Die Sowjetunion und die deutsche Frage. Studien zur sowjetischen Deutschlandpolitik von Stalin bis Chruschtschow, Göttingen: Vandenhoeck \&Ruprecht, 2007.

Loth, Wilfried: "Explaining European Integration: The Contribution fromHistorians", in: Journal of European Integration History 14 (2008/1), 9-26.

Loth, Wilfried: "Sources of European Integration: The Meaning of Failed Interwar Politics and the Role of World War II", in: Ludger Kühnhardt (ed.), Crises in European Integration. Challenges and Responses, 1945 - 2005, New York / Oxford: Berghahn 2009, 19-32.

Marès, Antoine: “Central Europe in the 'Fifth' Enlargement of the European Union”, in: Wilfried Loth (ed.), Experiencing Europe. 50 Years of European Construction 1957-2007, BadenBaden: Nomos 2009, 326-345.

Müller, Wolfgang: "The Soviet Union and Early West European Integration", in: Journal of European Integration History 15 (2009/2), 67-85.

Narinsky, Mikhail M.: "Sovětský svaz a Marshallûv plán. Ještě k otázce sovětského veta", in: Soudobé dějiny 4 (1997/3-4), 479-491.

Parish, Scott D.: "The Marshall Plan, Soviet-American-Relations, and the Division of Europe, in: Norman Naimark / Leonid Gibianski (eds.), The Establishment of Communist Regimes in Eastern Europe, 1944-1949, Boulder, Co., 1997, 267-290.

Roberts, Geoffrey: Stalin's War. From World War to Cold War, 1939-1953, New Haven / London: Yale University Press, 2006.

Sainsbury, Keith: The Turning Point. Roosevelt, Stalin, Churchill and Chiang-Kai-Shek, 1943. The Moscow, Cairo and Teheran Conferences, Oxford /New York: Oxford University Press, 1985.

Spaak, Paul Henri: Memoiren eines Europäers, Hamburg: Hoffman und Campe, 1969.

Verheugen, Günter: Europa in der Krise. Für eine Neubegründung der europäischen Idee, Köln: Kiepenheuer \& Witsch, 2005.

Wandycz, Piotr S.: Czechoslovak-Polish Confederation and the Great Powers 1940-1943, Bloomington: Indiana University Publications, 1956.

Ziegerhofer-Prettenthaler, Anita:Botschafter Europas. Richard Nikolaus Coudenhove-Kalergi und die Paneuropa-Bewegung in den zwanziger und dreißiger Jahren, Vienna: Böhlau, 2004. 